\title{
FOUCAULT E A RUPTURA COM A REPRESENTAÇÃO
}

\section{Foucault and the rupture with representation}

\author{
Camila Jourdan*
}

\begin{abstract}
RESUMO
$\mathrm{O}$ artigo apresenta os elementos da ruptura de Foucault com o paradigma da representação, entendendo que tal ruptura também o aproxima da tradição anarquista. Para tanto, são revisadas as posições de Foucault sobre a relação entre teoria e prática; sua abordagem da linguagem enquanto discurso e sua noção de acontecimento. Desta forma, a Filosofia de Foucault é caracterizada como libertária exatamente na medida em que rompe com o papel fundante da representação e com tudo que se segue deste.
\end{abstract}

Palavras-chave: anarquismo; representação; Foucault.

\begin{abstract}
The paper presents the elements of Foucault's rupture with the paradigm of representation, understanding that this rupture also brings him closer to the anarchist tradition. To that end, Foucault's positions about the relation between theory and practice are reviewed; his approach to language as discourse and his notion of event. In this way, Foucault's Philosophy is characterized as libertarian exactly insofar as he breaks with the founding role of representation and with everything that follows from it.
\end{abstract}

Keywords: anarchism; representation; Foucault.

\footnotetext{
* É professora adjunta de Filosofia na Universidade Estadual do Rio de Janeiro. E-mail: camila.jourdan@gmail.com
} 


\section{Introdução}

Muito já foi escrito sobre a presença de elementos libertários no pensamento de Michel Foucault. O objetivo deste artigo não é exatamente retomar estes elementos, mas ressaltar a especificidade da recusa ao paradigma representacional em sua Filosofia. Tal como compreendemos, a ontologia anarquista se caracteriza fundamentalmente pela ruptura com a abordagem dualista da representação, o que se expressa tanto na recusa à separação entre teoria e prática, quanto na recusa à separação entre governantes e governados, Estado e sociedade, vida e forma de vida, abstrato e concreto. Nesses termos, a perspectiva anarquista se aproxima de uma Filosofia da imanência, o que se expressa já no federalismo libertário, como resposta coerente à organização social enquanto instância da Uno-multiplicidade ontológica; na dialética serial phroudhoniana, enquanto uma proposta de compreensão da dialética que não se realiza por meio de uma harmonia sintética; bem como na compreensão de que a ação concreta factual é capaz de determinar o âmbito em princípio. Neste texto, não retomaremos estes elementos diretamente no pensamento anarquista clássico, mas nos deteremos na presença dos mesmos na abordagem que Foucault faz do papel dos intelectuais e da relação entre teoria e prática; do funcionamento da linguagem enquanto discurso e da noção de 'acontecimento' enquanto materialidade concreta que abre um campo de possíveis.

\section{Da recusa à separação entre teoria e prática}

Muitos são os modos pelos quais as defesas de Foucault se aproximam dos posicionamentos mantidos pelos anarquistas clássicos e contemporâneos. Guardadas as devidas proporções relativas às suas críticas ao humanismo moderno, à centralidade das opressões econômicas ou à manutenção do valor trabalho, vemos com Foucault ressurgir de modo radical muitos elementos presentes em pensadores 
como Bakunin e na crítica geral anarquista ao papel do Estado. No prólogo que Foucault escreve ao Antiédipo (1972), de Deleuze e Guattari, ele debocha dos militantes comunistas, qualificando-se como "tristes burocratas de revolução" e "funcionários da verdade". Para ele, os maiores inimigos da humanidade seriam os valores fascistas dissolvidos e disfarçados na sociedade moderna e o único modo ético de recusar tal fascismo seria rejeitar toda centralização, toda hierarquia e toda representação.

Os anarquistas sempre foram aqueles que reconheceram a existência da sociedade para além do Estado, independente deste e, inclusive, possibilitando-o. Há muito de comum na afirmação do caráter horizontal do exercício de poder entre Foucault e os primeiros libertários. De fato, apesar do contexto extremamente classista do século XIX, os anarquistas sempre foram aqueles que reconheceram, para além da luta de classes, a necessidade de se combater todas as demais opressões, inclusive no âmbito micro, em um processo emancipatório ou revolucionário, reconhecimento este que vem também acompanhado da identificação do papel dessas opressões na manutenção do sistema capitalista.

Juntamente à luta de classes e às desigualdades oriundas dela, haveriam mecanismos de controle e exclusão diretamente condicionados pelo heteropatriarcado, pela hegemonia branca, pela valorização da juventude, da magreza, de uma determinação do que é a sanidade mental e a perfeição física. Pensar as resistências não poderia ser pensar somente na emancipação da classe trabalhadora, seria necessário pensar também na luta contra as opressões às minorias e demais relações de dominação que atravessam nossa sociedade. As resistências às opressões teriam sua especificidade e também se relacionariam, claro, no sistema capitalista, à luta de classes, mas não do modo de um determinismo causal e mono direcional. As opressões se cruzariam, se fundamentariam e manteriam umas às outras do mesmo modo que as resistências também poderiam se sobrepor e se auxiliarem mutuamente.

Se é contra o poder que se luta, então todos aqueles sobre quem o poder se exerce como abuso, todos aqueles que o reconhecem como intolerável, podem começar a luta 
onde se encontram e a partir de sua atividade (ou passividade) própria. E iniciando esta luta -- que é a luta deles - de que conhecem perfeitamente o alvo e de que podem determinar o método, eles entram no processo revolucionário. Evidentemente como aliado do proletariado pois, se o poder se exerce como ele se exerce, é para manter a exploração capitalista. Eles servem realmente à causa da revolução proletária lutando precisamente onde a opressão se exerce sobre eles. As mulheres, os prisioneiros, os soldados, os doentes nos hospitais, os homossexuais iniciaram uma luta específica contra a forma particular de poder, de coerção, de controle que se exerce sobre eles. Estas lutas fazem parte atualmente do movimento revolucionário, com a condição de que sejam radicais, sem compromisso nem reformismo, sem tentativa de reorganizar o mesmo poder apenas com uma mudança de titular. E, na medida em que devem combater todos os controles e coerções que reproduzem o mesmo poder em todos os lugares, esses movimentos estão ligados ao movimento revolucionário do proletariado. (FOUCAULT, 1998, pp.77-78)

Para além da desconfiança crítica de Foucault para com todas as vias institucionais e o sistema legal, vemos ainda ressurgir no pensador a recusa a toda e qualquer vanguarda que poderia, na luta revolucionária, guiar as massas rumo a uma suposta verdade emancipatória. Foucault denuncia isto como não apenas fadado ao fracasso, mas também como reproduzindo e contribuindo com a manutenção das opressões que se pretendia superar. De acordo com o marxismo leninista, a consciência socialista seria levada à classe proletária por intelectuais, de origem burguesa. A perspectiva anarquista, defendida por autores como Bakunin (1978), é justamente a de que a emancipação socialista só pode ser formada a partir das lutas concretas e da vivência real e amarga do próprio povo. Bakunin defende diretamente a auto-organização das massas em corpos autônomos, federalizados de baixo para cima. Rejeitando a teoria de uma consciência de classe levada de fora, os anarquistas sempre se opuseram às crenças em "vanguardas esclarecidas" que buscam guiar as "massas". Defendendo a autonomia e um processo de 
aprendizagem coletivo, os anarquistas, em suas principais lutas, foram os que, como se sabe, sustentaram a máxima pela qual "a emancipação dos trabalhadores será obra dos próprios trabalhadores", sem necessidade de guias nem tutores. Em Foucault, vemos justamente aparecer a defesa clara pela qual se colocar supostamente a serviço teórico das massas já seria um modo de dominação. Neste contexto, o papel da relação entre teoria e prática é fundamental porque não apenas a teoria não pode ser vista como determinando a prática, assim como o privilégio desta última significa também a afirmação do caráter inseparável destas. A teoria nada mais seria do que uma parte da prática, não restando espaço para o intelectual que meramente pensa a realidade em seu gabinete, que contribui de fora para a formação de uma verdade, seja a proletária seja a ideologia burguesa. Em máximo grau, não restando lugar de todo para o "puro intelectual", não há alguém que age e alguém que teoriza sobre isso, não há a massa e a vanguarda, o povo se emancipa na medida em que produz sua própria verdade, na medida em que toma os discursos para si. O intelectual não apenas não pode representar as massas, ele não precisa fazê-lo, ele não deve sequer tentar, ou ele luta junto ou ele já está lutando contra. A teoria só pode ser uma parte da luta, ou se luta lado a lado ou se luta do outro lado.

Parece-me que a politização de um intelectual tradicionalmente se fazia a partir de duas coisas: em primeiro lugar, sua posição de intelectual na sociedade burguesa, no sistema de produção capitalista, na ideologia que ela produz ou impõe (ser explorado, reduzido à miséria, rejeitado, maldito, acusado de subversão, de imoralidade, etc...); em segundo lugar, seu próprio discurso, enquanto revelava uma determinada verdade, descobria relações políticas onde normalmente não eram percebidas. Estas duas formas de politização não eram estranhas uma em relação à outra, embora não coincidissem necessariamente. Havia o tipo de intelectual maldito e o tipo de intelectual socialista. Estas duas formas de politização facilmente se confundiram em determinados momentos de reação violenta do poder, depois de 1848, depois da Comuna de Paris, depois de 
1940: o intelectual era rejeitado, perseguido, no momento mesmo em que as coisas apareciam em sua "verdade", no momento em que não se devia dizer que o rei estava nu. $\mathrm{O}$ intelectual dizia a verdade àqueles que ainda não a viam e em nome daqueles que não podiam dizê-la: consciência e eloquência. Ora, o que os intelectuais descobriram recentemente é que as massas não necessitam deles para saber; elas sabem perfeitamente, claramente, muito melhor do que eles; e elas o dizem muito bem. Mas existe um sistema de poder que barra, proíbe, invalida este discurso e este saber. Poder que não se encontra somente nas instâncias superiores da censura, mas que penetra muito profundamente, muito sutilmente em toda trama da sociedade. Os próprios intelectuais fazem parte deste sistema de poder, a ideia de que eles são agentes da consciência e do discurso também faz parte deste sistema. O papel do intelectual não é mais do se colocar um pouco na frente, um pouco de lado para dizer muda verdade de todos; é antes o de lutas contra as formas de poder exatamente onde ele é, ao mesmo tempo, objeto e instrumento: na ordem do saber, da 'verdade' da 'consciência', do discurso." (FOUCAULT, 1998, p.71)

A crítica à noção moderna de representação como central, no âmbito epistemológico, que acompanha Foucault, aparece, então, também no âmbito político. Se o saber não é fundamentalmente representação de uma realidade externa, como nos fizeram crer toda uma gama de pensadores desde Descartes, mas é também e, antes de tudo, criação, também o exercício de poder como transferência é falho, o poder exerce-se diretamente e, se pode em alguns casos adquirir caráter representativo, é apenas por meio desse exercício direto, que não pode, portanto, ser jamais substituído ou suplantado pela representação. Sobre isso, é ainda interessante o que nos diz Deleuze sobre Foucault:

A meu ver você foi o primeiro a nos ensinar - tanto em seus livros quanto no domínio da prática - algo de 
fundamental: a indignidade de falar pelos outros. Quero dizer que se ridicularizava a representação, dizia-se que ela tinha acabado, mas não se tirava a consequência desta conversão teórica, isto é, que a teoria exigia que as pessoas a quem ela concerne falassem por elas mesmas. (DELEUZE, Em: FOUCAULT, 1998, p.72)

O diálogo entre Deleuze e Foucault sobre o papel dos intelectuais funda justamente a recusa da separação rígida entre teoria e prática e na ruptura que isso implica para o paradigma representacional. Deleuze define assim a teoria como um revezamento de práticas, e a prática como um revezamento de teorias. Não se trata de colocar a teoria a serviço da revolução, mas de negar o Uno do representante, pela multiplicidade da ação, pois a ação múltipla não seria a ação mais fraca, muito pelo contrário, a multiplicidade é o que tornaria uma ação mais potente.

Quando você organizou o GIP (Grupo de Informações das Prisões) foi baseado nisso: criar condições para que os presos pudessem falar por si mesmos. Seria totalmente falso dizer, como parecia dizer o maoista, que você teria passado à prática, aplicando suas teorias. Não havia aplicação, nem projeto de reforma, nem pesquisa no sentido tradicional. Havia uma coisa totalmente diferente: um sistema de revezamentos em um conjunto, em uma multiplicidade de componentes, ao mesmo tempo, teóricos e práticos. Para nós, o intelectual teórico deixou de ser um sujeito, uma consciência representante ou representativa. Aqueles que agem e lutam deixaram de ser representados, seja por um partido ou um sindicato que arrogaria o direito de ser a consciência deles. Quem fala e age? Sempre uma multiplicidade, mesmo que seja na pessoa que fala ou age. Nós somos todos pequenos grupos. Não existe mais representação, só existe ação: ação de teoria, ação de prática em relações de revezamento ou em rede. (DELEUZE, Em: FOUCAULT, 1998, p.70) 
Nega-se aqui a posição de vanguarda intelectual ao mesmo tempo em que se nega a noção de intelectual engajado, o típico portavoz das massas, aquele que deveria se colocar a serviço da revolução não lutando nas ruas, mas escrevendo textos tão somente. Dizer a verdade do outro já é dominação, você não pode servir à revolução assim, você só pode servir à manutenção do status quo estabelecido. Esta é talvez a grande diferença entre a posição de Sartre no Em defesa dos Intelectuais e a posição de Foucault aqui. Sartre diz que o intelectual não consegue representar as massas porque o papel que ocupa não foi forjado para isso, mas que ele deve pelo menos desmascarar isso, lutar para conseguir desconstruir esta condição e se tornar um teórico da revolução. Foucault e Deleuze aqui dizem: o intelectual não pode e não precisa representar o povo, o melhor que ele pode fazer é tomar parte na luta do lugar que ocupa e isso passa pela própria desconstrução de certos dispositivos constituintes historicamente da sua posição. E este inclusive teria sido um dos problemas do Estado soviético, a casta intelectual, o papel dos tecnocratas e cientistas como mantendo inalteradas as micro-relações de dominação social.

A teoria-prática é aquela que serve pra alguma coisa, não é o discurso totalizante, não é o discurso da representação, que busca a essência, a origem fundamental, mas é o particular que multiplica, que dá voz ao que é silenciado, que serve como arma na guerra de discursos. A teoria-prática não representa, ela age.

\section{Da linguagem enquanto discurso}

A crítica à noção de representação relacionada às resistências políticas é particularmente presente na abordagem que Foucault desenvolve da linguagem em toda a sua obra e, sobretudo, na aula inaugural de 2 de dezembro de 1970 no College de France, reunida na publicação $A$ ordem do discurso. Nesta aula, Foucault parte da linguagem como ato de discurso e, assim, como causa do sujeito. Discurso não subjetivo, portanto, não dito por alguém, mas que forja 
em ato aquele que o diz pelo ato mesmo de dizê-lo. A linguagem não vêm assim de uma mente existente em potência para depois se atualizar, a linguagem em ato criaria aquilo que chegamos a chamar subjetividade. É portanto uma compreensão da linguagem enquanto ação que se opõe à linguagem como representação, de uma maneira que facilmente podemos atrelar à defesa de um materialismo semântico.

(...) inquietação diante do que é o discurso em sua realidade material de coisa pronunciada ou escrita; inquietação diante de uma existência que é transitória e destinada a desaparecer sem dúvida, mas segundo uma duração que não nos pertence, inquietação de sentir sob essa atividade, todavia cotidiana e cinzenta, poderes e perigos que mal imagina; inquietação de supor lutas, vitórias, ferimentos, dominações, servidões, através de tantas palavras cujo uso há tanto tempo reduziu as asperidades. (FOUCAULT, 1970, p.08)

Os discursos inserem-se sempre em relações de poder que instauram jogos de forças. Ora, tratar a linguagem como discurso, antes do que como representação, é uma escolha em tratá-la como evento vivo, material, contextual e, também, como ação bélica e política no mundo. A linguagem desta forma é entendida principalmente como ação discursiva dentro de um jogo de forças e não como correspondendo a entidades semânticas abstratas previamente dadas ou a uma capacidade racional, mental, fundante do que seja o ser humano. É o discurso que gera o humano e não o humano que gera o discurso. Mais do que isso, trata-se de enfocar o discurso nele mesmo, como ação, e não como apontando para algo externo ao qual poderia ou não corresponder.

Dito de modo geral, podemos formular que não é a linguagem que se deriva da natureza humana previamente dada, mas que aquilo mesmo que entendemos por uma natureza humana universal, geral, definidora se segue de determinados jogos de forças discursivos passiveis de criar sentidos e aquilo mesmo que chegamos 
a entender como humano em certo contexto histórico. Mas é a ação, a prática política humana, e particularmente os jogos de forças no exercício de poder e dominação que está na base, e não uma natureza ou capacidade humana abstrata que garantiria a significação. $\mathrm{O}$ discurso é realidade material e local das lutas, há um exercício de poder no uso das palavras.

O discurso tem o caráter do acontecimento, ou seja, ele se distancia da representação, que é sempre secundária, e não uma verdade direta, e se efetiva sempre no âmbito da materialidade: "o discurso possui seu lugar e consiste na relação, coexistência, dispersão, recorte, acumulação, seleção de elementos materiais" (FOUCAULT, 2015, p.57) ${ }^{1}$ Entender a crítica ao humanismo de Foucault é entender a crítica a esta suposta natureza abstrata geral. A linguagem é discurso e o discurso não boia no vazio das representações, seja na mente do sujeito ou na realidade platônica, ele se insere e funda um jogo de forças discursivo, isto é, ele é todo, de ponta a ponta, relações de poder. Quem pode falar e o que pode falar varia contextualmente, entender a linguagem supõe toda uma relação de forças que é fundamentalmente semântica. Existiria uma via de mão dupla entre o discurso e o poder: "o discurso não é simplesmente aquilo que traduz as lutas ou os sistemas de dominação, mas aquilo por que, pelo que, se luta, o poder do qual nós queremos nos apoderar" (FOUCAULT, 1970, p.10).

De acordo com Foucault, os discursos na sociedade são controlados, selecionados e organizados. Uma das formas de manter esse controle é através das instituições, as quais instauram e/ou reproduzem os discursos. Por isso sua crítica à representatividade se relaciona diretamente também com suas críticas às instituições.

Parece-me que a verdadeira tarefa política, em uma sociedade como a nossa, é criticar o funcionamento das instituições, que dão a impressão de ser neutras e

1 Entendemos que esta abordagem é unificadora da sua filosofia, desde que o paradigma da representação, como verdade unificante acerca do modo como o conhecimento e a linguagem funcionam, isto é, o paradigma moderno por excelência, é colocado em questão desde a sua chamada "fase arqueológica". 
independentes; criticá-las e atacá-las de tal maneira que a violência política, que sempre foi exercida de maneira obscura, por meio delas seja desmascarada, para que se possa combatê-las. (FOUCAULT, 2014, p. 51)

A abordagem do discurso como acontecimento antes do que como representação é também uma continuação da sua crítica à suposta neutralidade científica que pretende desmascará-la como arma discursiva e exercício de poder ao mesmo tempo que continua sua crítica à noção de 'ideologia', desde que esta pareceria se opôr a um discurso não ideológico, isto é, neutro. Não se trata de dizer que alguns discursos são ideológicos e distorcem a realidade, enquanto outros podem representar a realidade adequadamente, mas de ressaltar que todo discurso é, de ponta a ponta, exercício de poder e que apelar para uma suposta neutralidade nada mais é do que uma arma muito eficaz, tanto mais eficaz quanto mais consegue esconder seu caráter de arma, como se acessasse a realidade pelada nela mesma, para além de interpretações superestruturais (culturais). Trata-se de demonstrar em que sentido o discurso da verdade, ainda que polido e contido, ainda que belamente racional, é extremamente violento.

Certamente, se nos situamos no nível de uma proposição, no interior de um discurso, a separação entre o verdadeiro e o falso não é nem arbitrária, nem modificável, nem institucional, nem violenta. Mas se nos situarmos em outra escala, se levantamos a questão de saber qual foi, qual é constantemente através de nossos discursos, essa vontade de verdade que atravessou tantos séculos de nossa história, ou qual é, em sua forma muito geral, o tipo de separação que rege nossa vontade de saber, então é talvez algo como um sistema de exclusão (sistema histórico, institucionalmente constrangedor) que vemos desenhar-se. (FOUCAULT, 1970, p. 13-14)

Nesse sentido, a 'vontade de verdade' científica, fundada no sistema de representação, exerce coerção e não pode ser jamais 
libertadora senão como um ardil muito bem articulado na guerra de discursos. No interior de um discurso há um critério de verdade bem delimitado, Foucault não está negando isso, mas o que estabeleceu este critério foi um jogo de forças e exercício direto de poder que a própria representação não é capaz de colocar em questão. Isso também significa dizer que este critério não é neutro, universal e estabelecido de uma vez por todas. À verdade como representação moderna, Foucault opõe então a verdade como ato, que cria panos de fundo e instaura necessidades. Haveria um "verdadeiro" de fundo (instaurado pelo acontecimento) que não seria do âmbito da representação, que mudaria historicamente e inclusive em relação ao qual a representação teria que se situar para ser julgada verdadeira ou falsa. ${ }^{2}$

Em suma, Foucault identifica os grandes rituais de sujeição dos discursos que se inserem na educação, na pertença aos grupos (criação de identidades), nas religiões, na Academia, nas apropriações sociais, em seus códigos e qualificações próprias, e que atingem tanto aqueles que proferem estes discursos quanto aqueles que os ouvem ou a quem eles se dirigem (dupla sujeição) (Conf:: FOUCAULT, 1970, p. 41-42).

A isso Foucault contrapõe as resistências discursivas que supõem fundamentalmente resgatar o caráter do discurso como acontecimento, que seria também resgatar seu caráter estrategicamente escondido pela representação, sempre situada entre o pensar e o dizer, de instaurador de necessidades. Então trata-se de não ver mais a linguagem como a roupa do pensamento ou "um pensamento revestido de signos e tornado visível pelas palavras" (FOUCAULT, 1970, p.44), mas de tornar evidente como a realidade do discurso foi escondida. E tal realidade discursiva teria sido escondida pelo tripé da representação, cujos elementos constituem a visão tradicional da linguagem com a qual sua compreensão como acontecimento pretende romper.

A representação elide a materialidade do discurso, seus perigos, suas possibilidades subversivas colocando-o na ordem do significante. Isso é o que Foucault chamou soberania do significante, um exercício de poder que se exerce na linguagem sob a ótica de sua essência pretensamente representacional. A linguagem não revela

2 Ver também: FOUCAULT, 1970, pp. 32-33. 
regularidades universais a prioris ou dadas em nossa mente, ela é uma violência que se instaura em práticas concretas e só nessas práticas os discursos instauram regularidades. "Quatro noções devem servir, portanto, de princípio regulador para a análise: a noção de acontecimento, a de série, a de regularidade, a de condição de possibilidade. Vemos que se opõem termo a termo: o acontecimento à criação, a série à unidade, a regularidade à originalidade e a condição de possibilidade à significação." (FOUCAULT, 1970, p. 51) Ou seja, a linguagem não é a criação original de um sujeito uno correspondendo como significante a uma significação dada em algum lugar (mente ou realidade). $\mathrm{O}$ discurso é um acontecimento que instaura regularidades (necessidades) numa série múltipla dentro de um determinado contexto. Ele opõe aqui a busca histórica do acontecimento singular ao estruturalismo do qual quer se diferenciar, uma oposição que é também a do descontínuo e do contínuo, pois o acontecimento é também ruptura e a estrutura uma continuidade. Neste contexto, ele estabelece a seguinte definição de acontecimento:

Certamente o acontecimento não é nem substância, nem acidente, nem qualidade, nem processo; o acontecimento não é da ordem dos corpos. Entretanto, ele não é imaterial; é sempre no âmbito da materialidade que ele se efetiva, que é efeito; ele possui seu lugar e consiste na relação, coexistência, dispersão, recorte, acumulação, seleção de elementos materiais; não é ato ou propriedade de um corpo; produz-se como efeito de e em uma dispersão material. Digamos que a filosofia do acontecimento deveria avançar na direção paradoxal, à primeira vista, de um materialismo do incorporal. (FOUCAULT, 1970, p. 54)

Pra além do dualismo mente e corpos, dualismo próprio ao paradigma da representação, Foucault nos fala aqui de um colapso entre um âmbito e outro no acontecimento, que instaura uma forma, confere um estatuto formal à matéria. Nisso, vemos muito bem o vínculo de Foucault com um materialismo que lhe é muito próprio e sobre o qual falaremos ainda adiante. 


\section{Do poder-corpo enquanto acontecimento}

A entrevista sob o título Verdade e Poder nos fornece pistas para pensar a importância dos eventos de maio de 68 no pensamento de Foucault e também a sua crítica ao estruturalismo, que dialoga diretamente com sua ruptura com o paradigma da representação. Nós sabemos que a chamada 'arqueologia' de Foucault já foi muito associada ao estruturalismo, como se naquele momento Foucault estivesse preocupado em descrever as estruturas fundamentais da produção de conhecimentos em determinada época. Como se sabe, o estruturalismo também é uma corrente de pensamento que toma para si a tarefa de descobrir estruturas que sustentam todos os âmbitos da realidade atividade humana. Nessa entrevista, Foucault associa à tarefa genealógica a sua tarefa naquele momento, quase como sendo um complemento desta primeira tarefa que se preocuparia então com as relações de poder inerentes a essas produções de saberes. Não haveria assim contraposição entre as duas propostas, ainda que elas sejam distintas, e ele faz isso ao mesmo tempo em que diz: "eu não vejo quem possa ser mais anti-estruturalista do que eu". Nesse sentido, ele associa a genealogia à arqueologia, exatamente no sentido em que procura se afastar do estruturalismo. E por que? Porque o estruturalismo estaria, tal como Foucault o entende, justamente no banimento da noção de 'acontecimento' da História. "Admite-se que o estruturalismo tenha sido o esforço mais sistemático para eliminar, não apenas da etnologia mas de uma série de outras ciências e até da história, o conceito de acontecimento." (1998, p.05) Entender o que isso significa pode ser o ponta pé inicial para entendermos sua ruptura com o paradigma da representação. A filosofia de Foucault, na medida em que se foca nas relações de 'saber-poder' se foca no acontecimento, ou seja, não pressupõe o dualismo mente e corpo próprio ao paradigma da representação, mas se interessa "pelos efeitos do poder que é próprio ao jogo enunciativo". Trata-se, portanto, já aqui da linguagem pensada como ação discursiva dentro de um jogo de forças e não como fundamentalmente representação que pressupõe uma dicotomia bem delimitada, isto é, de um lado o significado, de outro o significante, mas também de um lado o saber e de outro o exercício do poder, mas também de um lado o 
representante e de outro o representado, mas também de um lado a mente e de outro o corpo.

O estruturalismo, por sua vez, partiria sempre do jogo da representação, seu modo de pensar as estruturas subjacentes à realidade humana partem do modelo da linguística, particularmente da noção que a realidade humana é sempre linguística e se funda, portanto, no significado, ou melhor, é significativa, e sua estrutura subjacente deve então ser revelada a partir do modelo da estrutura do signo, que separa sempre de um lado um significado e de outro um significante. $\mathrm{Ou}$, poderíamos dizer também, de um lado um representado e de outro um representante, ao mesmo tempo em que coloca o peso, o privilégio necessariamente neste último, opondo a langue e a parole. Ainda que o estruturalismo seja uma ruptura com uma noção de linguagem mentalista, fundada nas intenções subjetivas, as mediações que as estruturas estabelecem entre um âmbito concreto (parole) e um âmbito abstrato (langue) são sempre representacionais, mesmo que estas representações ou mediações possam se dar de várias maneiras distintas.

$\mathrm{O}$ estruturalismo de Saussure privilegia a langue em detrimento da parole, considerando a primeira como um sistema sincrônico abstrato, constituído pelos padrões de formação subjacentes aos enunciados reais. Por outro lado, a parole nada mais seria do que tais enunciados reais ou comportamentos linguísticos atuais, que instanciariam as estruturas abstratas, responsáveis pela determinação em princípio do significado. Temos, portanto, uma oposição entre a enunciação concreta e o sistema da língua. Ora, Foucault sempre pretendeu pensar as condições das produções discursivas históricas, mas Foucault as pensa como produtos de um jogo de forças, capazes de produzir verdades e subjetividades. Nesse sentido, não é a concepção de Linguagem fundada na estrutura do signo, não são estas discursividades, que Foucault quer associar o seu projeto.

Nem a dialética (como lógica da contradição), nem a semiótica (como estrutura da comunicação) poderiam dar conta do que é a inteligibilidade intrínseca dos confrontos. A dialética é uma maneira de evitar a realidade aleatória e aberta desta inteligibilidade, 
reduzindo-a ao esqueleto hegeliano. ${ }^{3}$; semiologia é uma maneira de evitar seu caráter violento, sangrento e mortal, reduzindo-a a forma apaziguada e platônica da linguagem e do diálogo. (FOUCAULT, 1998, p.5)

É interessante notar também que no mesmo momento que Foucault se distancia do estruturalismo, do modelo do signo, ele faz questão de se distanciar ainda da dialética. Ora, em grande medida a dialética pode ser entendida como uma lógica das tensões, que permite pensar as contradições e romper com um dualismo de substâncias próprio ao esquema representacional do qual Foucault quer se afastar, entretanto, não é essa contradição domesticada pela síntese que o modelo genealógico quer reviver, as relações de força produtoras de discursividades afirmativas não se encaixam no modelo hegeliano.

Creio que aquilo que se deve ter como referência não é o grande modelo da língua e dos signos, mas sim da guerra e das batalhas. A historicidade que nos domina e nos determina é belicosa e não linguística. Relação de poder e não relação de sentido. A história não tem sentido, o que não quer dizer que seja absurda ou incoerente. Ao contrário, é inteligível e deve poder ser analisada nos seus menores detalhes, mas segundo a inteligibilidade das lutas, das estratégias e das táticas. (FOUCAULT, 1998, p.5)

Claramente Foucault coloca em cheque as principais dicotomias que permeiam a representação, não apenas o significado e o significante, a forma e a matéria, portanto, mas também o sujeito e o objeto dos saberes como instâncias substancialmente separadas e até mesmo a distinção muito cara ao materialismo dialético entre superestrutura e infraestrutura, na qual a primeira seria um mero efeito discursivo e cultural (epistêmico ou ideal) de um âmbito

3 Tese-Antítese-Síntese 
fundamental econômico (relações de produções materiais). Pensar a imanência das produções discursivas por meio do binômio saberpoder significa também romper com uma relação causal unidirecional neste sentido, mas entender que estes âmbitos se constituem mutuamente, mas é na realidade concreta dos jogos de forças que elas se constituem mutuamente. Isso significa também recusar a noção de ideologia de Marx, como um efeito superestrutural que mascara uma verdade material. A noção de ideologia suporia uma verdade neutra, um acesso ao real pelado, e todas as dicotomias próprias à noção de verdade como correspondência com as quais Foucault não pode coerentemente se comprometer. Se o ideológico é o desvio do raio do conhecimento, isso apenas faz sentido supondo-se o raio sem desvio ou a coisa em si kantiana, que só existe (e só pode existir) no dualismo representacional. Mas as produções discursivas de verdade são já o próprio raio que permite instaurar até mesmo as dicotomias. Não podemos dizer que "tudo é já ideológico" sem esvaziar a noção de ideologia de um sentido que se deriva da sua oposição ao nãoideológico.

A noção de ideologia me parece dificilmente utilizável por três razões. A primeira é que, queira-se ou não, ela está sempre em oposição virtual a alguma coisa que seria a verdade. Ora, creio que o problema não é de se fazer a partilha entre o que num discurso releva a cientificidade e da verdade e o que relevaria de outra coisa; mas de ver historicamente como se produzem efeitos de verdade no interior de discursos que não em si nem verdadeiros nem falsos. Segundo inconveniente: refere-se necessariamente a alguma coisa como o sujeito. Enfim, a ideologia está em posição secundária a alguma coisa que deve funcionar para ela como infraestrutura ou determinação econômica, material, etc. Por estas três razões creio que é uma noção que não deve ser utilizada sem precauções. (FOUCAULT, 1998, p.7)

A ênfase da genealogia é na discórdia, na tensão, nas rupturas, e não na síntese harmonizante das contradições históricas. 
(...) não seu segredo essencial e sem data, mas o segredo que elas são sem essência, ou que sua essência foi construída peça por peça a partir das figuras que lhe eram estranhas. A razão? Mas ela nasceu de uma maneira inteiramente 'desrazoável' - do acaso. A dedicação à verdade e ao rigor dos métodos científicos? Da paixão dos cientistas, de seus ódios recíprocos, de suas discussões fanáticas e sempre retomadas, da necessidade de suprimir as paixões - armas longamente forjadas ao longo das lutas pessoais. E a liberdade, seria ela, na raiz do homem o que o liga ao ser e à verdade? De fato, ela é apenas uma invenção das classes dominantes. (FOUCAULT, 1998, p. 18)

O atual, o concreto, não esteve sempre dado em um em princípio estabelecido desde o ponto de vista da eternidade, ele é produto da luta contínua das dominações. Interessante notar que Foucault não fala na luta de classes como motor histórico, mas ressalta a multiplicidade das dominações e das revoltas dos oprimidos como as tensões que estariam na base da emergência do totalmente outro.

Por exemplo, a emergência de uma espécie (animal ou humana) e sua solidez são asseguradas por um longo combate contra condições constantes e essencialmente desfavoráveis. De fato, 'a espécie tem necessidade da espécie enquanto espécie como de qualquer coisa que, graças à sua dureza, à sua uniformidade, à simplicidade de sua forma, pode se impor e se tornar durável na luta perpétua com os vizinhos ou os oprimidos em revolta'. (FOUCAULT, 1998, p.23)

Assim, ele define 'acontecimento' como o momento de ruptura no qual a relação de forças se inverte. Momento que é ao mesmo tempo da resistência e o da produção de verdades. Aqui fica claro que esta verdade produzida no jogo de forças e não simplesmente descoberta não pode ser a verdade da representação, a 
representação não poderia ser um produto da luta histórica como Foucault pretende mostrar.

Podem-se apreender a partir de então as características próprias do sentido histórico como Nietzsche o entende, e que opõe a "Wirkliche Historie" à história tradicional. Aquela inverte a relação habitualmente estabelecida entre a irrupção do acontecimento e a necessidade continua. Há toda uma tradição da história (teleológica ou racionalista) que tende a dissolver o acontecimento singular em uma continuidade ideal - movimento teleológico ou encadeamento natural. A história "efetiva" faz ressurgir o acontecimento no que ele pode ter de único e agudo. É preciso entender por acontecimento não uma decisão, um tratado, um reino, ou uma batalha, mas uma relação de forças que se inverte, um poder confiscado, um vocabulário retomado e voltado contra seus utilizadores, uma dominação que se enfraquece, se distende, se envenena e uma outra que faz sua entrada, mascarada. As forças que se encontram em jogo na história não obedecem nem a uma destinação, nem a uma mecânica, mas ao acaso da luta. Elas não se manifestam como formas sucessivas de uma intenção primordial; como também não têm o aspecto de um resultado. Elas aparecem sempre na áurea singular do acontecimento. (FOUCAULT, 1998, p. 28)

Retomamos, assim, a materialismo do acontecimento em Foucault. As análises foucaultiana do poder-corpo podem ser usadas para pensar sua relação com o materialismo, relação crítica sem dúvida, na medida em que a Matéria, seria já uma abstração e Foucault pretende resgatar o corpo em sua concretude. Sem dúvida, então, não é por se aproximar de um idealismo que Foucault poderia ser dito recusar o Materialismo Histórico, mas talvez por radicalizar certos pressupostos de retorno ao concreto e suas potências imanentes. Sobre isso, é Roberto Machado quem nos apresenta um Foucault em certo sentido mais materialista do que a leitura ortodoxa do pensamento de Marx: 
Uma grande novidade que essa pesquisa atual tem apresentado é a de não procurar as condições de possibilidades históricas das ciências humanas nas relações de produção, na infraestrutura material, situando-as como uma resultante superestrutural, um epifenômeno, um efeito ideológico. A questão não é a de relacionar o saber considerado como ideia, pensamento, fenômeno de consciência - diretamente com a economia, situando a consciência dos homens como reflexo e expressão das condições econômicas. O que faz a genealogia é considerar o saber - compreendido como materialidade, como prática, como acontecimento - como peça de um dispositivo político que, enquanto dispositivo, se articula com a estrutra econômica. Ou, mais especificamente, a questão tem sido a de como se formaram domínios do saber - que foram chamados de ciências humanas - a partir de práticas políticas disciplinares. (MACHADO, R. Em: FOUCAULT, 1998, p. XXI)

Não é o saber um efeito de produções materiais, não há determinismo econômico neste sentido. Abrir mão do binômio mente e corpo próprio à representação deve ser levado a sério, isso significa que realmente não há uma relação separada entre o concreto e o abstrato, mas que o saber é ele mesmo uma prática, uma materialidade, um acontecimento discursivo e não uma representação de uma realidade independente. Também por isso Foucault rejeita a noção de ideologia, como efeito superestrutural, ele então se coloca como mais materialista do que o próprio materialismo de Marx:

Acho que eu me distinguo tanto da perspectiva marxista quanto da para-marxista. Quanto à primeira, eu não sou dos que tentam delimitar os efeitos de poder ao nível da ideologia. Eu me pergunto se, antes de colocar a questão da ideologia, não seria mais materialista estudar a questão do corpo, dos efeitos do poder sobre ele. Pois o que me incomoda nestas análises que privilegiam a ideologia é que sempre se supõe um sujeito humano, cujo modelo foi fornecido pela filosofia clássica, que seria 
dotado de uma consciência de que o poder viria se apoderar. (FOUCAULT, 1998, p. 148)

Seria preciso se livrar ainda do Hegel que habita em Marx, jogar fora a consciência subjetiva junto com o idealismo dialético. E nesse sentido seria preciso resgatar o materialismo para além destas noções de consciência e ideologia.

(...) se há coisas muito interessantes sobre o corpo em Marx, o marxismo - enquanto realidade histórica -as ocultou terrivelmente em proveito da consciência e da ideologia... É preciso se distinguir dos para-marxistas como Marcuse, que dão à noção de repressão uma importância exagerada. Pois se o poder só tivesse a função de reprimir, se agisse apenas por meio da censura, da exclusão, do impedimento, do recalcamento, à maneira de um grande super-ego, se apenas se exercesse de um modo negativo, ele seria muito frágil. Se ele é forte, é porque produz efeitos positivos a nível do desejo. (FOUCAULT, 1998, p. 148)

Dito isso, o poder-corpo é também o poder exercido para além da (e contra a) noção de representação. Não é aquele que representa a República una e indivisível, o corpo do soberano como unidade das múltiplas vontades representadas (Hobbes), mas o corpo múltiplo da sociedade, sem correspondência a uma abstração transcendente. É preciso atestar a existência desse poder concreto que é produtivo de saberes, criador, afirmativo. O poder na sociedade moderna não viria da repressão, mas também não viria da alma, da consciência, da idealidade, nada seria mais físico, mais material, que o exercício do poder.

O exercício do poder nos corpos é seu aspecto material, que se opõe à universalidade das vontades que seria alcançada pelo suposto consenso da representação. Não há consenso justificando a dominação, em máximo grau, há exercício de poder direto nos corpos, entendido estes mesmos como possibilidades de resistências. 
Assim Foucault analisa o movimento das resistências e suas reações, as estratégias dos jogos de força: a cada movimento de um adversário corresponde uma resposta, isso está no indefinido das lutas, das batalhas, não é um projeto previamente estabelecido, por isso nenhuma vitória está dada, por isso nenhum fim da História estaria garantido.

Como resposta à revolta do corpo, encontramos um novo investimento que não tem mais a forma de controle-repressão, mas de controle-estimulação: 'Fique nu, mas seja magro, bonito, bronzeado!' A cada movimento de um dos dois adversários corresponde o movimento do outro. Mas não é uma "recuperação" no sentido em que falam os esquerdistas. E preciso aceitar o indefinido da luta... O que não quer dizer que ela não acabará um dia. (FOUCAULT, 1998, p. 147)

E novamente aqui Foucault retoma a questão da separação entre intelectuais e não intelectuais na sua crítica a tomada do aparelho do Estado. Se o poder está no corpo, e não na mente, ele também não está no Uno e sim no múltiplo. Como nos disse Deleuze, em outro contexto, sem dúvida, talvez isso seja o que podemos entender por se ser de esquerda, ser de esquerda não tem nenhuma relação com querer tomar o Estado, com querer se constituir como um aparelho de Estado.

Realmente, os movimentos revolucionários marxistas ou influenciados pelo marxismo, a partir do final do século XIX, privilegiaram o aparelho de Estado como alvo da luta. A que foi que isto levou? Para poder lutar contra um Estado que não é apenas um governo, é preciso que o movimento revolucionário se atribua o equivalente em termos de forças político-militares, que ele se constitua, portanto, como partido, organizado - interiormente - como um aparelho de Estado, com os mesmos mecanismos de disciplina, as mesmas hierarquias, a mesma organização de poderes. 
Esta consequência é grave. Em segundo lugar, a tomada do aparelho de Estado - esta foi uma grande discussão no interior do próprio marxismo - deve ser considerada como uma simples ocupação com modificações eventuais ou deve ser a ocasião de sua destruição? Você sabe como finalmente se resolveu este problema: é preciso minar o aparelho, mas não completamente, já que quando a ditadura do proletariado se estabelecer, a luta de classes não estará, por conseguinte, terminada... E preciso, portanto, que o aparelho de Estado esteja suficientemente intacto para que se possa utilizá-lo contra os inimigos de classe. Chegamos à segunda consequência: o aparelho de Estado deve ser mantido, pelo menos até um certo ponto, durante a ditadura do proletariado. Finalmente, terceira consequência: para fazer funcionar estes aparelhos de Estado que serão ocupados mas não destruídos, convém apelar para os técnicos e os especialistas. E, para isto, utiliza-se a antiga classe familiarizada com o aparelho, isto é, a burguesia. Eis, sem dúvida, o que se passou na U.R.S.S. Eu não estou querendo dizer que o aparelho de Estado não seja importante, mas me parece que, entre todas as condições que se deve reunir para não recomeçar a experiência soviética, para que o processo revolucionário não seja interrompido, uma das primeiras coisas a compreender é que o poder não está localizado no aparelho de Estado e que nada mudará na sociedade se os mecanismos de poder que funcionam fora, abaixo, ao lado dos aparelhos de Estado a um nível muito mais elementar, quotidiano, não forem modificados. (FOUCAULT, 1998, p. 149)

E aqui a posição de Foucault é extremamente libertária: tratase de criticar o Estado dentro dos movimentos revolucionários, ou mesmo, o Estado que há em cada um de nós. 


\section{Conclusão}

Face ao exposto, vimos que o pensamento de Foucault se aproxima da abordagem anarquista precisamente naqueles pontos em que rompe com o paradigma representacional: na recusa aos dualismos; na manutenção das tensões em detrimento das sínteses; na afirmação de uma concretude capaz de forjar possibilidades pelos acontecimentos. Foucault coloca em cheque as principais dicotomias que permeiam a representação, não apenas o significado e $o$ significante, a forma e a matéria, mas também o sujeito e o objeto dos saberes como instâncias substancialmente separadas e até mesmo a distinção muito cara ao materialismo dialético entre superestrutura e infraestrutura, na qual a primeira seria um mero efeito discursivo e cultural (epistêmico ou ideal) de um âmbito fundamental econômico (relações de produções materiais). Pensar a imanência das produções discursivas por meio do binômio saber-poder significa não apenas romper com uma relação causal unidirecional neste sentido, mas entender que estes âmbitos se constituem mutuamente. Isso significa também recusar a noção de ideologia de Marx, como um efeito superestrutural que mascara uma verdade material. Mas se Foucault critica a dialética é por afirmar a tensão, a luta, as batalhas, em detrimento das sínteses totalizantes. Se ele nega o materialismo é ainda para melhor afirmar o corpo. Uma ontologia do múltiplo, das tensões, das relações, do concreto em contraposição ao paradigma representacional: consideramos que estes são aspectos muito próprios à tradição anarquista e libertária, ao que estes pensamentos carregam de diferentes tanto do liberalismo quanto do socialismo de Estado.

\section{Referências}

BOTTOMORE, T. Dicionário do Pensamento Marxista. Trad. Jorge Zahar Editor. Rio de Janeiro, Jorge Zahar. 1988.

ERIBON, Didier. Michel Foucault. Trad. Leonardo, Milão, 1991. 
DELEUZE, Gilles; GUATARRI, Félix. $O$ Antiédipo: capitalismo e esquizofrenia. Trad. Joana Moraes Varela e Manuel Maria Carrilha, 1972.

DELEUZE, G.; GUATARRI, F. (1984) "Maio de 68 não ocorreu" Trad. Mariana de Toledo Barbosa. Revista Trágica: estudos de filosofia da imanência $-1^{\circ}$ quadrimestre de $2015-$ Vol. $8-\mathrm{n}^{\circ} 1-$ pp.119-121

FOUCAULT, M. As palavras e as coisas. Trad. Salma Tannus Muchail. São Paulo: Martins Fontes, 1999.

FOUCAULT, Michel. Dits et Ecrits. Daniel Defert et François Ewald (Org.). Paris: Gallimard, 1994.

FOUCAULT, Michel. Microfisica do poder. Trad. Roberto Machado. Rio de Janeiro: Graal, 1998.

FOUCAULT, Michel. "O sujeito e o poder, Michel Foucault uma trajetória filosófica". Michel Foucault. Uma trajetória filosófica. Para além do estruturalismo e da hermenêutica. Hubert Dreyfus e Paul Rabinow (Org.). Rio de Janeiro: Forense Universitária, 1997, pp.231-249.

FOUCAULT, Michel. "A ética do cuidado de si como prática da liberdade" (entrevista com H. Backer e R. Fornet-Betancourt em 20 de janeiro de 1984). Revista Internacional de Filosofia, julhodezembro, 1984.

FOUCAULT, Michel. “Qu' est-ce que les Lumières". Magazine Littéraire, n 309, abril de 1993, pp.61-74.

FOUCAULT, Michel. Últimas entrevistas. Rio de Janeiro: Taurus, 1986.

FOUCAULT, M. A Ordem do Discurso. São Paulo: Loyola, 1996.

RECEBIDO EM: 14/05/2019

APROVADO EM: 13/06/2019 